\title{
REFLEXÕES SOBRE A TEORIA PURA DO DIREITO À LUZ DA CONTRADIÇÃO HUMANA E DA MITOLOGIA
}

\section{THOUGHTS ON THE THEORY OF RIGHT TO PURE LIGHT OF HUMAN CONTRADICTION AND MYTHOLOGY}

\author{
${ }^{1}$ Clovis Alberto Volpe Filho
}

\begin{abstract}
RESUMO
$\mathrm{O}$ artigo busca analisar possíveis liames entre a teoria pura do direito com a natureza contraditória do ser humano e a mitologia. Partindo da ideia de que o direito, como produto do homem, é um mito na concepção ficcional, criado como instrumento de evitar que a contradição humana seja um obstáculo intransponível à convivência social. Enfim, pretende-se entender que o direito tem fundamento mítico, além de compreender que isto não retira sua legitimidade e racionalidade, ao contrário, nos possibilita evoluir, sendo a pureza do direito proposta por Kelsen um instrumento para tentar regular da melhor maneira possível a contradição humana.
\end{abstract}

Palavras-chave: Fundamento do direito; mito; contradição; relativização de valores; teoria pura do direito.

\begin{abstract}
This article seeks to analyze possible bonds between the pure theory of law with the contradictory nature of human beings and mythology. Starting from the idea that the right, as human product, is a myth in the fictional design, created as a tool to prevent human contradiction is an insurmountable obstacle to social harmony. Finally, we intend to understand that the right has mythical basis, and understand that this does not take away its legitimacy and rationality, by contrast, allows us to evolve, and the purity of the law proposed by Kelsen an instrument to try to regulate in the best way possible human contradiction.
\end{abstract}

Keywords: Right Foundation; myth; contradiction; relativization of values; pure theory of law.

\footnotetext{
${ }^{1}$ Doutorando em Direito Constitucional pela Faculdade Autônoma de Direito - FADISP, São Paulo, (Brasil). Especialista em Ciências Criminais. Advogado. Professor em Direito da Faculdade Doutor Francisco Maeda - FAFRAM, São Paulo. E-mail: clovisvolpe@ hotmail.com
} 


\section{INTRODUÇÃO}

Em um clássico conto de Machado de Assis, o Diabo funda uma igreja para ter um instrumento que consiga regular os homens e atingir maior eficácia contra Deus. "Igreja contra Igreja" anuncia o Diabo em dada passagem do conto. Após anunciar a Deus sua nova obra, o Diabo voltou a terra e espalhou sua "doutrina nova e extraordinária, com uma voz que reboava nas entranhas do século" (ASSIS, 1884). O pano de fundo dessa "nova doutrina" era a inversão de "valores", onde, por exemplo, os chamados sete pecados capitais se transformariam em novas virtudes; assim, avareza passou a ser mãe da economia e a inveja passou a ser virtude principal, origem de propriedades infinitas.

Para se ter uma exata noção desta "nova doutrina", eis uma passagem do conto:

A venalidade, disse o Diabo, era o exercício de um direito superior a todos os direitos. Se tu podes vender a tua casa, o teu boi, o teu sapato, o teu chapéu, coisas que são tuas por uma razão jurídica e legal, mas que, em todo caso, estão fora de ti, como é que não podes vender a tua opinião, o teu voto, a tua palavra, a tua fé, coisas que são mais do que tuas, porque são a tua própria consciência, isto é, tu mesmo? Negá-lo é cair no absurdo e no contraditório. Pois não há mulheres que vendem os cabelos? não pode um homem vender uma parte do seu sangue para transfundi-lo a outro homem anêmico? e o sangue e os cabelos, partes físicas, terão um privilégio que se nega ao caráter, à porção moral do homem? (ASSIS, 1884)

Em verdade, o Diabo pretendia com a nova Igreja arrebatar fiéis pelos seus próprios pecados, pois dizia ele: as virtudes, filhas do céu, são em grande número comparáveis as rainhas, cujo manto de veludo rematasse em franjas de algodão. Ora, eu proponho-me a puxálas por essa franja, e trazê-las todas para minha igreja; atrás delas virão as de seda pura... (ASSIS, 1884)

Com essa base doutrinária a Igreja do Diabo difundiu-se exponencialmente, não havendo uma região do globo que não a conhecesse, uma língua que não a traduzisse e uma raça que não a amasse.

No entanto, com o tempo, o Diabo percebeu que seus fiéis estavam, às escuras, praticando as antigas virtudes. Àqueles que deviam ser avarentos davam esmolas em locais ermos - entre outras virtudes relacionadas à Igreja de Deus; alguns pregadores do Diabo estavam frequentando a Igreja de Deus disfarçadamente; dilapidadores do erário restituíam-lhe pequenas quantias; enfim, havia a prática do pecado às avessas no reino do Satanás. 
Diante desse cenário, não teve dúvidas, meteu-se a falar com Deus. Trêmulo de raiva, contou toda a agonia que estava passando com sua empreitada religiosa e aguardou a simples resposta de Deus:

Que queres tu, meu pobre Diabo? As capas de algodão têm agora franjas de seda, como as de veludo tiveram franjas de algodão. Que queres tu? É a eterna contradição humana. (ASSIS, 1884)

As palavras do escritor falam por si: o mal e o bem, o belo e o feio, o justo e o injusto, o pecado e a virtude, possuem partes antagônicas em si. O mais maléfico, apresenta também fios de benevolência; o mais horrendo traz traços de beleza aplacadora; o mais justo tem as bordas coroadas de injustiça; o mais pecador apresenta atos virtuosos que dão inveja a qualquer missionário religioso.

Tudo a depender do ser em si, da perspectiva alheia e das circunstâncias.

Mas, afinal, no que este conto se relaciona com o presente artigo? Nada e tudo. Nada em razão de estar relacionado com a literatura sobre a contradição humana, e não com o direito. Tudo, pois é esta mesma natureza humana que criou o direito, e é esse mesmo direito que recepciona e controla (ou tenta controlar) a contradição humana.

E é isto que vamos discorrer nos tópicos seguintes: direito como instrumento de recepção e controle da contradição humana, sendo sua legitimidade ancorada na mitologia.

\section{CONTRADIÇÃO HUMANA}

A pretensão deste artigo, bem como a delimitação de conteúdo, não permite avançar vertical e horizontalmente sobre a contradição humana. Assim, faz-se necessário realizar um corte metodológico, para fornecer um conceito (mínimo e seguro) do que se entende por contradição humana.

A premissa que adoto ${ }^{2}$, para tanto, é que o homem, enquanto ser pensante, inventou o conhecimento, e este não é de sua natureza. Em verdade, e seguindo Nietzsche, o conhecimento foi inventado a partir do momento que os instintos se confrontam, se unem, se comprometem e desse jogo resulta o conhecimento. O conhecimento é o efeito dos instintos, ou, "uma centelha entre duas espadas", não se confundindo com as espadas (FOUCAULT, 2013, p. 25-26).

\footnotetext{
${ }^{2}$ Utilizarei a primeira pessoa para ter coerência com o que se pretende: reflexões.
} 
O que me interessa é justamente a conclusão de que o conhecimento é uma invenção, e não algo instintivo, apesar deste resultar. Em sendo assim, sempre haverá da luta (ou do compromisso) entre os instintos várias possibilidades.

O ser humano é contraditório, pois, o conhecimento nasce de um jogo em que o resultado não é previamente definido. Daí a razão de Nietzsche entender que a moral não é um dado intrínseco da natureza do homem. Rompe-se, com uma visão pacificadora dessa mesma natureza, que considera o homem como naturalmente suscetível aos valores morais, em razão de sua qualidade de ser originariamente social e racional (GIACOIA, 2000, p. 88).

O próprio Nietzsche consegue demonstrar, de forma ilustrativa, como valores morais somente são alocados a posteriori pela régua adotada de acordo com determinados marcos (espaço, tempo, interesse, sociedade, cultura, etc):

Originalmente - assim eles decretam - as ações não egoístas foram louvadas e consideradas boas por aqueles aos quais eram úteis, mais tarde foi esquecida essa origem do louvor, e as ações não egoístas, pelo simples fato de terem sido costumeiramente tidas como boas, foram sentidas como boas - como se em si fossem algo bom. (NIETZSCHE, 1998, p. 18)

Sob uma outra perspectiva, a contradição humana é reflexo de valores alheios, e não uma contradição inerente de determinada pessoa. É dizer: se faz contraditória a partir da medida que está usando para mensurá-lo, se houver mudança, haverá coerência. Por isso que a avareza, em uma perspectiva rasa de um capitalista, pode ser uma virtude.

Afonso Cruz aponta diversas contradições cotidianas que refletem esta natureza, como este exemplo citado em seu livro temático: "A minha tia gosta muito de pássaros, mas prende-os em gaiolas. É uma pena" (CRUZ, 2010).

Aqui reside um bom exemplo: para classificar como contraditória a conduta da tia é preciso entender como "mau" o ato de prender passarinhos, mesmo gostando desta espécie de animais. Mas quem define se este ato é "bom" ou "mau"? Portanto, toda contradição humana vem de uma conclusão resultante de juízos de valores alocados sobre as condutas praticadas. E se este juízo de valor não é um dado absoluto e nem mesmo inerente da natureza humana, pois, como vimos, sempre existirão outras possibilidades.

Ora, o sul coreano, gosta tanto de cachorros que até come. "É uma pena”, diria um ocidental. Já os indianos diriam: "os ocidentais gostam tanto de vacas que até comem, ao invés de adorá-las". Obviamente são exemplos triviais que demonstram o quão relativa é a 
valoração da conduta humana, e por assim ser, a perfeição (daquele que pratica o ato e daquele que julga) é algo inalcançável, o que acarreta na eterna contradição humana.

O caminhar do ser humano não é reto, no sentido de perfeição, ao contrário, é torto, capenga, manco, por haver sempre duas ou mais valorações, sempre será relativo. O torto é o reto para alguns.

A falibilidade humana é uma característica irrenunciável, por isso criamos mitos, e destes advém regras e sanções (princípio da retribuição). Em outras palavras, a busca de sentido para a vida, para a finitude, para a fraqueza, para a dor, para a sobrevivência, e, principalmente, para a imposição de valores, projeta no ser humano a necessidade de criar mitos.

Note-se que a criação de mitos está associada com a contradição humana, e especificamente, na necessidade de se impor retidão neste antagonismo. A questão é que a convivência em sociedade impôs a necessidade de alguém (um grupo, um rei, um Deus, etc) impor esta retidão, impor o certo e o errado, e para tanto, criaram-se os mitos.

\section{CONTRADIÇÃO HUMANA E A MITOLOGIA}

Desde sempre os seres humanos criaram mitos. Karen Armstrong, em sua obra sobre a origem do mito, afirma expressamente que escavações arqueológicas comprovam tal tese. Além disso, a mesma autora assevera que o mito nasce dessa necessidade de dar sentido a algo menor para parecer mais valioso e com sentido:

Somos criaturas em busca de sentido. Os cães até onde sabemos, não sofrem agonias por sua condição canina, não se preocupam com o destino dos cães que habitam outras partes do mundo nem tentam ver a vida sob uma perspectiva diferente. Os seres humanos, por sua vez, facilmente se desesperam, e desde a origem mais remota inventamos histórias que permitem situar nossas vidas em um cenário mais amplo e nos dão a sensação de que a vida, apesar de todas as provas caóticas e arrasadoras em contrário possui um valor e significado. (ARMSTRONG, 2005, p. 1)

Neste sentido, é possível defender que é justamente o aspecto contraditório do ser humano (estar vivo e aguardar a morte é o mais emblemático) que faz ser necessário projetarmos mitos. Acrescento outro: a necessidade de definir a contradição como algo errado, para a imposição de um agir que se considera certo. 
O mito é fictício, como um romance, um jogo que transfigura nossa realidade e nos ajuda a vislumbrar novas possibilidades ao perguntar “e se?” (ARMSTRONG, 2005, p. 5). Tal questão é uma das mais importantes da humanidade, pois, de tanto criarmos ficções, o "e se" em vários casos transformou-se em realidade. "E se o homem voasse?"; dessa pergunta, fez-se o avião e espaço naves.

No entanto, a ficção que o ser humano faz é, em primeira ordem, não para criar realidade, mas para dar conta da realidade existente. É dizer: a adoração ao Sol não se dava em razão do entendimento deste astro enquanto estrela, mas sim para buscar a salvação no sagrado de algo terreno que o perturbava.

Diziam os antigos: "Se não for oferecido um sacrifício ao Deus Sol haverá trevas! E se for oferecido haverá paz!"

A mitologia nos auxilia, também, na compreensão da domesticação das atitudes humanas. O mito do paraíso (ou o seu antonino, o mito do inferno) ajuda a condicionar as condutas humanas. Tanto que Karen Armstrong afirma que um mito é verdadeiro por ser eficaz, e não por fornecer dados factuais; a mitologia somente transformará se seguirmos suas diretrizes, pois o mito é essencialmente um guia ARMSTRONG, 2005, p. 6).

Matthew Kneale afirma, em sua obra sobre crença, que o fundamento de todas as religiões é a confiança, pois toda a religião inventa mitos para confortar às pessoas, proporcionando-lhes maneiras de manter distantes de seus piores pesadelos, e acrescento, de alcançar seus prêmios (KNEALE, 2016, p. 11). Outro ponto interessante aludido por Kneale é a necessidade do sacrifício, como forma de retribuição à proteção ou ao prêmio alcançado. Aqui deita raiz na reciprocidade, que é vínculo importante na relação humana de toda a ordem, inclusive com o sobrenatural. Ora, "se os seres sobrenaturais iriam nos proteger dos nossos pesadelos, assim como os seres humanos, eles com certeza esperariam algo em troca" (KNEALE, 2016, p. 11). A proporção nasce justamente da ideia de recompensar o grandioso alcançado com algo de igual ou maior monta.

A religião mesopotâmica não tinha acento em nenhum aspecto moral moralidade que conhecemos; o certo e o errado era analisado de acordo com o cumprimento dos rituais complexos, e não com o comportamento com o outro (KNEALE, 2016, p. 17). É justamente em razão dessa complexa ritualística de compensação que os mesopotâmicos inventam o pecado. Não o pecado como concebemos atualmente, mas seu gene, que está relacionado com erro e punição. O mal da lavoura, a infelicidade do feto deformado, era um 
sinal de punição dos deuses, ou seja, a punição era a prova da culpa. Assim, quando uma família passava por um dissabor, a origem estava em não ter honrado corretamente determinado deus.

Veja o paradoxo bem lembrado por Alain Supiot: “À finitude de sua vida orgânica e visceral sobrepõe-se o mundo sem limites de suas representações mentais" (SUPIOT, 2007, P.5). A precariedade da vida humana na terra é sustentada pela infinidade do pensamento humano. E este pensamento projeta mitos, para que possamos dar conta da realidade.

Logo, torna-se possível sustentar que a busca por explicar a natureza e regrar as relações humanas implicaram e implicam na criação de mitos.

\section{MITOLOGIA E O DIREITO}

A estrutura de uma comunidade primitiva era baseada no misticismo, que envolvia a crença e o medo, sempre permeado pela ideia de retribuição (CARNIO, 2013, p. 4546). Este é o ponto nodal: entender que o mito está amparado pela correlação de crença e retribuição (punição ou prêmio).

A existência de mitos, em qualquer era, por mais que estes se modifiquem, sempre ampara a correlação entre crença e retribuição. A presença do mito mais antigo até um mito moderno está amparada pela crença (crer, acreditar) do ser humano, com a possibilidade de lhe ser retribuído algo, não importando o valor dado a este algo.

Portanto, na linha de Henrique Garbellini, a sociedade mais longínqua conduzia suas relações sociais pelo princípio da retribuição (CARNIO, 2013, p. 56-57). E este princípio se impõe tanto horizontalmente (nas relações entre as pessoas), como verticalmente (nas relações sobre-humanas). Ocorre que há uma interligação emocional entre as relações horizontais e verticais, pois a compreensão do mundo e o regramento da vida social se dava a partir do pensamento mítico. O mesmo fundamento da punição do membro da sociedade que comia o fruto proibido estava presente nas oferendas ao divino.

A constatação que me interessa é justamente que o mito, o tabu, mais primitivo já era uma norma social, sendo incorreto falar em transformação de tabu em norma social (CARNIO, 2013, p. 64).

Um raciocínio linear poderia assim ser desenvolvido: o ser humano primitivo para dar conta das contradições do homem, do mundo e das relações humanas criou a crença em mitos; desta crença originou-se a retribuição, como forma de entender, se manter e tentar 
regular/controlar o mundo e a convivência com o próximo; portanto, a regulação social nasce do mito.

E toda forma de regulação social (religiosa, moral ou jurídica) tem, em primeira e última análise, fundamento no mito. Utilizando-se de analogia, é possível entender que o mito do Deus onipresente, onisciente e onipotente tem a mesma essência do Direito, ou seja, o pensamento mítico.

Hans Kelsen, em um texto pouco difundido, aduz que a vivência religiosa se cristaliza em uma autoridade situada por cima do indivíduo, a qual condiciona sua existência e determina seu comportamento. Se comparada a autoridade do sistema normativo não há diferença alguma, pois esta também invade e conduz a consciência do cidadão (KELSEN, 1989, p. 244). Avançando sobre o tema Deus e Estado, Kelsen alega que não pode causar surpresa que a teoria do Estado, a teoria da construção deste ente mais completo de todas as construções sociais, apresente notáveis coincidências com a Doutrina de Deus: a teologia (KELSEN, 1989, p. 251).

Nas palavras do autor:

El Estado también es concebido essecialmente como persona, y como tal constituye tan sóla la personificación de un orde: el ordem jurídico. Concebir como unidad la multiplicidad de las relaciones jurídicas de los indivíduos, tal es la función posibilitada por el concepto de orden jurídico. Pero la unidad abstracta del oden jurídico se plasma em la representación de una persona, cuya voluntad significa el contenido de este orden jurídico, de la misma manera que la voluntad de Dios se expressa em el orden del mundo (KELSEN, 1989, p. 252).

Refinando a argumentação, o citado autor faz um interessante paralelo entre o conceito de soberania e Deus, aproximando o Estado Soberano de Deus supremo, e quando a soberania de um Estado é interpretada como poder absoluto, não se trata de outra coisa senão aquele poder que toda teologia afirma como essência de um Deus. (KELSEN, 1989, p. 254).

Arrebatadora é a passagem em que concilia a ideia de sujeito de direitos (pessoa física ou jurídica) com a ideia de alma, pois, segundo Kelsen, da mesma forma que o homem não aparece no sistema teleológico como criatura física, o direito também não toma o homem como unidade biológica-psicológica, mas sim como pessoa, um sujeito de direito. De sorte, que na medida em que a Igreja vê o homem a imagem e semelhança de Deus, o Estado olha o homem como sua imagem e semelhança, pessoa de direito por excelência (KELSEN, 1989, p. 264). 
Há, portanto, pontos comuns, similares e congruentes entre o pensamento mítico e o pensamento jurídico.

\section{TEORIA PURA DO DIREITO E A CONTRADIÇÃO HUMANA}

Neste tópico pretendo responder a seguinte indagação: por qual razão a ciência do direito é pura, na visão de Kelsen? A resposta, construída a seguir, caminhará ao encontro da contradição humana.

Hans Kelsen não separou Direito de Moral, mas sim Ciência do Direito de Moral. A não compreensão desta frase conduz a erros e distorções homéricas. Na visão de Hans Kelsen, a Teoria Pura empreende delimitar o conhecimento do Direito em face das outras disciplinas, não por ignorá-las, nem mesmo por negar conexões, mas porque tenciona evitar um sincretismo metodológico que obscurece a essência da ciência jurídica (KELSEN, 1979, p. 18).

Para o referido autor é necessário entender que todas as normas que constituem fundamento dos juízos de valor são estabelecidas por atos arbitrários, pois são relativos; assim, a validade da norma fica adstrita a valores subjetivos e relativos, podendo gerar contradições a partir da visão do valor que constitui a norma: o que é bom segundo uma norma, pode ser mau segundo outra (KELSEN, 1979, p. 39).

Fixada a premissa de que não existe moral absoluta (relacionada com juízo de valor), o autor adverte que o direito enquanto norma, apesar de ter a mesma forma (dever-ser), não tem o mesmo conteúdo. Eis as palavras de Hans Kelsen:

A afirmação de que o Direito é, por sua essência, moral, não significa que ele tenha um determinado conteúdo, mas que ele é norma e uma norma social que estabelece, com caráter de devida (como devendo-ser), uma determinada conduta humana. Então, neste sentido relativo, todo o direito tem caráter moral, todo o Direito constitui um valor moral relativo. Isto, porém, quer dizer: a questão das relações entre o Direito e a Moral não é uma questão sobre o conteúdo do Direito, mas uma questão sobre a sua forma (KELSEN, 1979, p. 103).

Note-se que Hans Kelsen aproxima o direito da moral em sua forma (norma), e adverte, que por ser relativo, a moral não é conteúdo do direito. E isto tem total relação com lógica arquitetada pelo autor, pois se a moral é relativa, a norma jurídica que contemple um juízo de valor "y" não deixa de ser norma jurídica se comparada a outra norma jurídica de outro sistema que contempla um juízo de valor antagônico ao " $y$ ". 
Assim, a ciência jurídica não aprova e nem desaprova o seu objeto; "embora as normas jurídicas, como as prescrições do dever-ser, constituam valores, a tarefa da ciência jurídica não é de forma alguma uma valoração ou apreciação do seu objeto, mas uma descrição alheia a valores" (KELSEN, 1979, p. 106).

Denota-se que o autor diferenciou os momentos da análise dos juízos de valores: não se aplica a norma à luz da justiça, mas sim com base na sua aplicação ao caso concreto, face a validade normativa conferida pelo próprio ordenamento, em uma visão escalonada.

A ciência do direito não poderia ser justa/injusta, tendo em vista que tal juízo é relativo. Desejar que o ordenamento jurídico, para ser caracterizado como Direito seja justo, é esquecer da contradição da natureza humana e da relatividade do juízo de valor.

A Igreja do Diabo não deixa de ser Igreja por ser do Diabo! Não me atrevo nesta doutrina religiosa, mas não ignoro tal possibilidade. Isto porque, a Igreja é meio, instrumento, utilizado pelo homem. E é este que utiliza o instrumento conforme bem (ou mal) lhe prouver. A classificação da Igreja como sendo do Diabo já é relativa por essência, na medida em que para caracterizar como tal, preciso de parâmetros contrários, e, fatalmente, alguns parâmetros desta diabólica doutrina sustentam outras Igrejas que se dizem de Deus.

O Direito da Alemanha nazista não deixa de ser Direito por ser nazista! Não me atrevo nesta doutrina jurídica, mas não ignoro tal possibilidade. Com efeito, o Direito (leia-se, ciência do direito) é um instrumento, e suas normas, após aprovadas de acordo com o ordenamento jurídico em vigor estão imunes a juízos de valores, posto que, do contrário, teríamos um conflito insuperável e interminável de contradições. A classificação do Direito como imoral parte da premissa de que existe um Direito moral, porém, quando revelado que o conceito de moral é relativo, os polos podem se inverterem e aquele Direito avaliado como imoral pode ser moralmente aceito sobre outra perspectiva, já que não há moral absoluta.

O ciclo seria infinito e o paradoxo insuperável: haveriam juízes, ao mesmo tempo, fiéis e infiéis. Fiéis por cumprirem a norma; infiéis por não cumprirem; Fiéis aos olhos da justiça que (supostamente) não estava na norma; infiéis aos olhos da norma posta pelo poder competente. O Ditador de uma determinada nação vai perguntar porque são infiéis aqueles que querem a reforma; o grupo representativo de uma determinada democracia vai encalço da mesma indagação, questionando por que é infiel o grupo anarquista que repele qualquer regulação normativa. Ambos ouvirão o que Diabo ouviu de Deus quando questionou sobre os infiéis de sua Igreja: eterna contradição humana. 
Hanna Arendt compreendeu esta contradição (ARENDT, 1999) e não ficou isenta de críticas (principalmente da comunidade judaica); repito, o ser humano faz o bem com a mesma normalidade que faz o mal, pois para aquele que faz, em regra, o faz sob o manto (ainda frágil) de um (suposto) bem que o ampara. O cidadão norte-americano que mora no Texas/EUA, e que tem a obrigação de matar a pessoa condenada a pena de morte, o faz, em tese, pelo (suposto) bem da comunidade e pelo dever de cumprir a lei. O comandante que determinou a prisão de pessoas que queriam deixar uma pequena ilha na América Central o faz para o (suposto) bem de seu país e para cumprir as leis. Todos esses relatos podem ser questionados hoje ou amanhã, de dentro ou de fora, sendo o certo e o errado tão instável quanto o polônio. O que não é relativo é o cumprimento da norma legal.

A teoria de Hans Kelsen é pura para que haja um corte na raiz a evitar a contradição humana quando da aplicação da norma. E isto é útil, na medida em que possibilita abrigar as diversas contradições, distintas no espaço-tempo. Porém, o palco para a análise das contradições é anterior a criação da norma, sob pena de não haver fim a relativização valorativa de seu conteúdo.

Ao delimitar que a norma está isenta de juízos de valores impede a repetição do ciclo e do paradoxo, pois, justamente pela contradição humana, deixar a normatividade aberta ao critério do juiz, do sábio ou do pajé, é tão injusto e inseguro, do que fechar a normatividade pelo critério anteriormente posto pela própria norma produzida segundo critério previamente estabelecidos pela norma superior hierarquicamente.

Julgar a Teoria Pura como algo pejorativo, a possibilitar o encampação de matérias imorais, não é julgar a doutrina kelseniana, mas o próprio homem, que prefere julgar o instrumento à si próprio. Considerar uma moral absoluta, e portanto, um Direito moralmente aceito, é estancar a evolução da humanidade. Erros e atrocidades históricas são praticadas pelos homens, enquanto ser em (re)evolução, e não pelo Direito Puro ou Impuro.

\section{TEORIA PURA DO DIREITO E A MITOLOGIA}

Neste item, o que pretendo é responder esta indagação: Qual o fundamento primeiro da ordem jurídica, que possibilita a validade e aplicação de suas normas? Resposta: o mito.

O direito, por não estar no mundo do ser (causalidade), imputa aos membros da comunidade um dever de agir, sob pena de uma sanção. Em uma lógica superficial, a autoridade 
que detém o poder da produção normativa, intenta que algo aconteça ou não aconteça, mas como sua vontade não é uma relação causal de que vai ou não ser feito, imputa uma consequência para tentar que seja ou não realizado. Assim, tem-se que no mundo normativo, se A, deve-ser B. ${ }^{3}$

Percebam que a pergunta basilar de toda mitologia (e se?), está intimamente relacionada com a base da Teoria Pura do Direito: ser e dever-ser, pois o dever-ser nada mais é do que o "e se?". Com efeito, ao imputar uma conduta como proibida, por exemplo, o legislador almeja (a partir da indagação “e se?”) que a vida em sociedade seja mais harmoniosa na medida em que seus membros não pratiquem aquele ato. Para tanto, como não consegue exercer sobre eles um princípio causal, imputa um dever e condiciona o descumprimento a uma sanção.

Mas, qual a validade da norma que determina o cumprimento de uma obrigação, para se evitar a punição ou conquistar uma recompensa? A norma hierarquicamente superior. Mas quem conferiu validade a norma superior? Outra ainda mais superior (Constituição). E há um ponto final nesta hierarquia? Sim, responde Kelsen, a norma fundamental (grundnorm).

Afirma Hans Kelsen que "o fundamento de validade de uma ordem normativa é - como veremos - uma norma fundamental da qual se retira a validade de todas as normas pertencentes a essa ordem" (KELSEN, 1979, p. 57). Portanto, há uma norma fundamental que confere validade ao mundo do dever-ser.

Para este autor, o fundamento primeiro da ciência do direito não pode ser um fato, mas uma norma. Isto porque, "ao aceitar a irredutibilidade entre "ser" e "deve ser" (sein e sollen), Kelsen, na busca da fundamentação última da validade da ordem positiva, evita encontrar esse fundamento na realidade social, pois essa realidade está situada no mundo do “ser” (Sein), e a dedução de um “dever ser” a partir do ser é logicamente impossível” (BURITY, 1988 , p. 15). Porém, esta norma, que confere validade as normas positivas, inclusive a Constituição, não é positiva, mas meramente pensada.

Ela é uma pura ou "verdadeira" ficção no sentido da vaihingeriana Filosofia do Como-se, que é caracterizada pelo fato de que ela não somente contradiz a realidade, como também é contraditória em sim mesma. (KELSEN, 1986, p. 328).

O próprio Hans Kelsen reconhece que a ficção é um instrumento utilizado pelo pensamento quando não é possível alcançar o fim do pensamento com o material existente

\footnotetext{
${ }^{3}$ Nas palavras de Hans Kelsen: o princípio da causalidade afirma que, quando é A, B também é. O princípio da imputação afirma que, quando A é, B deve ser. (1979, p. 137).
} 
(KELSEN, 1986, p. 329). Acrescento que a ficção é também utilizada para tentar legitimar algo que não consegue ser legitimado pela realidade posta.

Aquilo que Kelsen denomina de ficção, com base na teoria do "como se", na verdade é um pensamento mítico. A norma fundamental é um mito contemporâneo, assim como Zeus era um mito da Grécia antiga e assim como o paraíso é um mito para o cristão.

O paraíso está para a religião assim como a ideia de justiça está para o direito. $\mathrm{O}$ mito do paraíso é a crença que, em maior parte, permite que o crente tenha confiança na vida eterna, para cumprir com todos os preceitos religiosos. O mito do big bang é a crença que os astrofísicos precisam ter para que o universo tenha um ponto de partida. O mito da justiça é a crença que, em maior parte, permite que o ser humano tenha confiança na segurança que o Estado lhe proporcionará, para que possa cumprir com todos os preceitos legais, abrindo mão da liberdade absoluta. O mito da norma fundamental é a crença que o jurista precisa ter para que a ciência do direito possua um ponto inicial a conferir validade a todo o sistema.

A Igreja projeta mitos para domesticar fiéis a cumprirem seus dogmas. O Estado projeta mitos para domesticar seus cidadãos a cumprirem suas leis. A noção da racionalidade legal é tão efêmera que não suporta uma década de análise. Dizer que a fé que sustenta a religião é diferente da racionalidade que direciona a lei, é tão equivocado como sustentar que a terra é plana. Pode até parecer pelo olhar cotidiano, mas uma análise mais apurada revelará que a base última da fé e da racionalidade é a mesma.

$\mathrm{O}$ ato de acreditar pela razão é mutável, e que aquilo que seria fé no passado, tornou-se racional no presente; E aquilo que era chamado de racional no passado, transmudouse para fé nos dias atuais. Há um marco zero, um ponto de encontro em ambas.

A lei eficaz não se relaciona com justiça, mas sim com confiança na ideia de justiça (ou mito da justiça) que determinado grupo detém. A democracia é um mito que sustenta vários Estados na modernidade - ou alguém acredita que realmente o poder emana do povo? Não emana, mas é preciso fazer acreditar (ter a crença) que emana.

Caso o poder emane do povo, o mito se torna realidade, sendo que tal realidade somente será possível ser sustentada se houver um novo mito que dê aporte. Havendo ou não juízo final, alguns cristãos precisam acreditar que existe. Caso o juízo final exista, será necessário outro mito para que se cumpra este juízo com eficácia. Enquanto houver realidade faceando nossos sentidos existirá mito para sustentá-la. Quando descobrimos que a terra não era plana, desconstruímos um mito, mas quantos outros vieram em razão disso? 
Daí a razão de Hans Vaihinger, segundo Hans Kelsen (KELSEN, 1986, p. 328), ter defendido que a ficção contradiz a realidade e a si mesma, pois mesmo que se sustente existir um big bang será questionado quem o acionou? E quem "acionou" aquele que acionou? Ou, no mundo das normas, se existe uma norma primeira, qual autoridade a colocou? Portanto, sempre haverá ficção, que traduzo por mito.

É o paradoxo que proponho: a concepção de mundo do ser humano, de realidade, somente se funda e perfaz na mitologia. Acredito na lei da gravidade, mas por de trás há um mar de mitos cosmológicos que a sustenta. Onde houver realidade há mito, e onde houver mito há um ser humano que acredita no real (o acreditar no real já é uma ficção em si). Portanto, o ser humano é um ser mitológico, pois ao mesmo tempo que cria mitos, é também um mito. Ora, se se considera qualquer pessoa posta em um espaço e um tempo determinado como uma dada realidade, com certeza há um mito por de trás, já que seu reconhecimento pressupõe que adveio de algum lugar - mas que lugar é este?. Isto já implica em uma resposta mitológica, ainda que em segundo ou terceiro plano.

O Direito tem fundamento mitológico, e sua eficácia somente é comprovada se os membros da sociedade acreditarem nos mitos que ele carrega (justiça, igualdade, e, entre outros, norma fundamental).

Hans Kelsen asseverou que a validade objetiva (e não formal) da norma ocorre com a sua eficácia.

Uma norma jurídica é considerada como objetivamente válida apenas quando a condutas humana que ela regula lhe corresponde efetivamente, pelo menos em certa medida (KELSEN, 1979, p. 30).

Tal afirmação se relaciona inteiramente com o conceito de mito, haja vista que um mito "é verdadeiro por ser eficaz, e não por fornecer dados factuais" (ARMSTRONG, 2005, p. 6). Logo, o Direito não é eficaz por ser de fato justo, bom ou útil, mas sim por que os membros da sociedade obedecem em grande medida seus comandos, por acreditarem (crerem) em algum valor que consideram justo, bom ou útil. Já a validade formal é conferida, segundo Hans Kelsen, pela confrontação com outra norma inserida no ordenamento jurídico.

A existência de uma revolução civil ocorre justamente em razão da comunidade não mais ter crença na ordem jurídica que lhe regula. O poder coercitivo está limitado pela ineficácia absoluta da norma (leia-se, ausência de crença nos proveitos ideais da norma), isto é, uma ordem jurídica somente se sustenta em uma comunidade se houver certa eficácia, sendo a ineficácia pontual remediada pela coação. O ordenamento jurídico, ramificado a partir da norma 
fundamental, autoriza os que detêm o poder a exercer a força (BOBBIO, 2008, p. 216); porém, a força é ineficaz quando for numerosa a descrença no poder que a conferiu, ou seja, no ordenamento jurídico.

A completa e irrestrita ineficácia gera o fim da ordem jurídica, posto que a sanção não é o remédio para a absoluta ineficácia. O caos gerado pela ineficácia generalizada não consegue ser contido com punições ou prêmios, é preciso que exista uma crença, ainda que difusa e fragmentada, permeando aquela comunidade.

Neste tom, a crença no sistema do Direito (que desemboca no fundamento mítico) é essencial para a sobrevivência do próprio Direito. Note-se que a comunidade alemã não extirpou o Direito construído pelo Partido Nacional Socialista dos Trabalhadores Alemães, sendo este eficaz. A extinção desse sistema jurídico veio de fora, em razão da Guerra vencida (se é que tem vencedor em Guerras) pelos Aliados. Porém, alguns sistemas jurídicos foram extirpados pela própria comunidade a ele submetida.

As palavras de Pierre Legendre, consignadas na obra de Fernanda Otoni de Barros, são esclarecedoras, na medida em que pontua que fazer crer é a grande arte do poder, pois crer no ordenamento outorga legitimidade a ele e o faz operar socialmente. Para Legendre a norma fundamental também "Ausente", no sentido de que somente pode ser pensada no registro da ficção; e é justamente em nome desse “Ausente”, que o Papa, o Rei, os Doutores, o Governadores, ditam as normas e os legisladores a escrevem e transmitem (LEGENDRE, apud BARROS, 2005, p. 17).

Para este jurista e historiador francês, a crença na ficção deve, para finalizar a operação ideal, resultar no amor. Esta tríade, ficção, crença e amor, ampara as normas sociais de diferentes matrizes, inclusive a jurídica. A obediência da norma fundamental está amparada no "Como se" essa ordem fosse determinada por uma autoridade, que detém o poder de obrigar (e validar), pois mantém a crença, entre seus filiados, de que os protegerá e amparará (LEGENDRE, apud BARROS, 2005, p. 18-19).

Em verdade, a ficção da norma fundamental consiste em fingir que existe uma autoridade mais elevada que os constituintes que autorizaram a criação da constituição (CORREAS, 2006, p. 248). Portanto, trata-se de um pensamento genuinamente mítico. É emblemático, assim, que a ficção ampare o sistema jurídico de Kelsen, e sua compreensão não faz desmoronar esta doutrina, ao contrário, a fortalece. 


\section{REFLEXÕES FINAIS}

$\mathrm{O}$ direito, enquanto norma, tem o mérito de justamente de proteger (e não blindar) as decisões da vida em sociedade (que chamo de decisão político-social) da contradição humana, partindo da premissa mítica do conceito de nação, Estado, lei, justiça, democracia, bem comum, igualdade, liberdade, norma fundamental, etc.

As reflexões aqui ventiladas têm como missão, primeiro, entender que a ciência do direito (teoria pura do direito) tem fundamento mítico. Em segundo lugar compreender que isto não retira sua legitimidade e racionalidade, ao contrário, nos possibilita avançar e evoluir. E por fim, enxergar que a pureza do direito proposta por Kelsen é justamente para dar conta da contradição humana, ou ao menos regular da melhor maneira possível.

“Cada parte conserva no todo quanto é por ele conservada, nenhuma é a primeira ou a última, o todo ganha clareza mediante cada parte, e a menor parte não pode ser plenamente compreendida sem que o todo já o tenha sido previamente" (SCHOPENHAUER, 2005, p. 1920). É por isso que devemos cumprir o papel da compreensão do sistema: entender a norma (átomo do ordenamento jurídico) necessita da compreensão prévia do todo que ela está inserida; entender o todo é saber o fundamento que está amparado. E a ideia sustentada é justamente que o todo tem raiz mitológica, e isto não inferioriza o homem dito moderno e racional, ao contrário, o eleva na compreensão de que sua vida somente se faz na crença do mito.

Enfim, a contradição humana bradada por Deus no conto machadiano revela a natureza do homem e sua necessidade de conviver o melhor possível com este dado; para tanto, cria-se mitos, entre eles, e o mais eficaz até então (até mais que a religião) o direito.

\section{REFERÊNCIAS}

ARENDT, Hannah. Eichmann em Jerusalém, um relato sobre a banalidade do mal. Tradução de José Rubens Siqueira. São Paulo: Companhia das Letras, 1999.

ARMSTRONG, Karen. Breve história do mito. Companhia das letras: 2005. 
ASSIS, Machado de. Volume de contos. Rio de Janeiro: Garnier, 1884. Disponível em: http://www.dominiopublico.gov.br/download/texto/bv000195.

BARROS, Fernanda Otoni de. Do direito ao pai. 2. ed. Belo Horizonte: Del Rey, 2005.

BOBBIO, Noberto. Teoria geral do direito. Trad. Denise Agostinetti. São Paulo: Martins Fontes, 2008.

BURITY, Tarcísio de Miranda. Kelsen e o pensamento conjectural. João Pessoa: A União, 1988.

CARNIO, Henrique Garbellini. Direito e Antropologia: reflexões sobre a origem do direito a partir de Kelsen e Nietzche. São Paulo: Saraiva, 2013.

CORREAS, Óscar. Y la norma fundante se hizo ficción. Apud. ANDRADE, Jacqueline Ortiz. El mito de Quetzalcoatl como fundamento "fictício" del derecho Azteca. In Revista Crítica Jurídica. . 25, jul/dic 2006, Unam.

CRUZ, Afonso. Contradição Humana. Portugal: Editora Caminho, 2010.

FOUCAULT, Michel. A verdade e as formas jurídicas. Rio de Janeiro: Nau Editora, 2013.

GIACOIA, Oswaldo. Genealogia da Moral e Arqueologia da Cultura, In: Assim Falou Nietzsche II, Rio de Janeiro, DP\&A, 2000.

KELSEN, Hans. Dios y Estado. In: El otro Kelsen. Universidad Nacional Autónoma de México, Institutos de Investigações Jurídicas: México, 1989. , Hans. Teoria das Normas. Trad. José Florentino Duarte. Porto Alegre: Sergio Antonio Fabris Editor, 1986. , Hans. Teoria pura do direito. 2. ed. Trad. João Baptista Machado. Coimbra: Editora Coimbra, 1979. 
KNEALE, Matthew. Crença: nossa invenção mais extraordinária. Trad. Fernando Santos. São Paulo: Martins Fontes, 2016.

NIETZSCHE, Friedrich. Genealogia da Moral: uma polêmica. Trad. Paulo César de Sousa. São Paulo: Companhia das Letras, 1998.

SCHOPENHAUER, Arthur. O mundo como vontade e como representação. Tradução João Barboza. São Paulo: Editora Unesp, 2005.

SUPIOT, Alain. Homo juridicus: ensaio sobre a função antropológica do direito. Trad. Maria Ermantina de Almeida Prado Galvão. São Paulo: Martins Fontes, 2007. 